\title{
Harmanlanmış Öğrenme Ortamında Denetim Odağına Göre Uyarlanmış 5E Öğrenme Modelinin Öğrencilerin Akademik Başarısına Etkisi*
}

\section{The Effects of 5E Learning Cycle Model in Adaptive Blended Learning Environment to Students' Academic Success}

\author{
Hakkı BAĞCI**
}

\author{
Halil İbrahim YALIN ${ }^{* * *}$
}

Received: 22 January 2018

Accepted: 28 March 2018

\begin{abstract}
In a blended learning environment, the effect of 5E model which was adapted according to the focus of control to students' academic success was examined in this research. The research was carried out in 2011-2012 academic year with two experimental and two control groups. Each group is comprised of Bozok University Vocational High School Computer Technologies Department, Computer Programming area consists of 104 students who take "Fundamentals of Programming-I" course which is in the first semester of 1st grade. Focus of Control Scale, Academic Success Test and Student Satisfaction about Blended Learning Environment Scale were used in order to collect data for the research. The academic success was measured with a pre-test post-test control group design. T-test, variance analysis (ANOVA) and covariance analysis (ANCOVA) were used in data analysis. According to the findings of the study, experimental groups had higher test scores than the control groups in academic achievement test. Moreover, it was found out that experimental groups had higher retention test scores when compared to the control groups.
\end{abstract}

Keywords: blended learning, focus of control, 5E model.

ÖZ: $\mathrm{Bu}$ araştırmada denetim odağına göre uyarlanmış harmanlanmış öğrenme ortamında 5E öğrenme modelinin öğrencilerin akademik başarılarına etkisi incelemiştir. Araştırma, 2011-2012 öğretim y1lı Bozok Üniversitesi Meslek Yüksek Okulu Bilgisayar Teknolojileri Bölümü Bilgisayar Programcılığı öğrencilerinden oluşan ve birinci sınıf, birinci yarıyıl programında bulunan "Programlama Temelleri I" dersini alan 104 öğrenci ile yürütülmüş̧ür. Araştırmada deneysel desen kullanılmıştır. Öğrenciler iki deney ve iki kontrol grubuna ayrılmıştır. Deney grubunda 53, kontrol grubunda ise 51 öğrenci bulunmaktadır. Hem deney hem de kontrol grubu harmanlanmış öğrenme ortamında bulunmuşlardır. Verilerin toplanmasında denetim odağı ölçeği ve akademik başarı testi kullanılmıştır. Araştırmada akademik başarı analizinde deneysel desen kullanılmıştır. Araştırmada elde edilen verilerin çözümlenmesinde t-testi, tek faktörlü varyans analizi (ANOVA) ve tek faktörlü kovaryans analizi (ANCOVA) kullanılmıştır. Araştırmada elde edilen bulgulara göre; 5E modeline uygun olarak denetim odağına göre uyarlanan harmanlanmış öğrenme ortamında ders alan öğrencilerin, harmanlanmış öğrenme ortamında ders alan öğrencilere göre daha yüksek başarı gösterdiği bulunmuştur. Aynı zamanda $5 \mathrm{E}$ öğrenme modeline göre ders alan öğrencilerin $5 \mathrm{E}$ öğrenme modelinden bağımsız harmanlanmış öğrenme ortamında ders alan öğrencilere göre başarılarının daha kalıcı olduğu sonucuna ulaşılmıştır.

Anahtar kelimeler: harmanlanmış öğrenme, denetim odağı, 5E öğrenme modeli.

\footnotetext{
* This study is a part of the first author's doctoral dissertation.

** Corresponding Author: Asst. Prof. Dr., Sakarya University, Sakarya, Turkey, hbagci@ sakarya.edu.tr

${ }^{* * *}$ Prof. Dr., Gazi University, Ankara, Turkey, hiyalin@gmail.com
}

Citation Information

Bağcı, H., \& Yalın, H. İ. (2018). Harmanlanmış öğrenme ortamında denetim odağına göre uyarlanmış 5E öğrenme modelinin öğrencilerin akademik başarısına etkisi. Kuramsal Eğitimbilim Dergisi [Journal of Theoretical Educational Science], 11(3), 562-585. 


\section{Giriş}

Ülkemizde bilgisayar ve teknoloji ile ilgili eğitim veren bölümler ve bu bölümlerin popülaritesi giderek artmaktadır. Bilgisayar Programcılığı, Bilgisayar ve Öğretim Teknolojileri Eğitimi (BÖTE), Bilgisayar Öğretmenliği, Bilgisayar Mühendisliği, Matematik ve İstatistik bu bölümlerden bazılarıdır. Bu bölümlerde programlama dilleri ile ilgili dersler verilmektedir. Programlama dilleri, her hangi bir programcının bilgisayarda gerçekleştireceği işlemleri hangi veriler üzerinden yapılacağını, bu verilerin nerelerde ve ne şekilde saklanıp iletileceğini, hangi şartlarda ve hangi olayların yapılacağının tam olarak anlatılmasına imkan verir. Herhangi bir programlama dili öğrenilmeden önce programlama mantığının öğrenilmesi önem taşımaktadır.

Programlama mantığı, diğer bir deyişle algoritma öğretimi programlama öğretiminin ilk ve en önemli basamağıdır (Arabacığlu, Bülbül \& Filiz, 2007). Algoritma, bir problemin çözümündeki işlemlerin, kararların ve bunların uygulanma sırasının oluşturduğu akış olarak düşünülebilir (Çelikkol, 2007). Programlamayı ilk defa öğrenen kişiler, bilgisayarın algoritmayı nasıl işlettiğini kavramakta zorlanırlar. Uygulamaya programlama bilgilerini aktarmanın dışında, öğrenileni üzerine eklemenin karmaşıklığını yaşarlar (Connolly, Murphy \& Moore, 2009).

Öğrencilerin algoritma konusundaki endişelerinin ve algoritmayı anlamakta çektikleri zorlukların üstesinden gelebilmeleri için bu konudaki deneyimlerini artırma gerekliliği ortaya çıkmaktadır. Algoritmanın öğrenilmesindeki bu güçlükleri aşabilmek için harmanlamış öğrenme ortamı alternatif bir öğrenme ortamı olarak düşünülebilir. "Harmanlanmış öğrenme, "doğru" becerileri "doğru" zamana "doğru" kişiye aktarmak için "doğru" öğrenme teknolojilerini "doğru" kişisel öğrenme stiliyle eşleştirerek öğrenme hedeflerine ulaşmayı uygun hale getirmeye odaklanır." (Singh \& Reed, 2001, s. 2).

Horton (2000), harmanlanmış öğrenmeyi web tabanlı öğrenme ve sinıf ortamında gerçekleştirilen öğrenmenin birleştirilerek, her iki ortamın avantajlı ve kuvvetli yönlerinin bir araya getirilmesi olarak tanımlamıştır. Harmanlanmış öğrenme ortamı oluşturulurken kullanıcıların özellikleri de dikkate alınmalıdır. Diğer bir deyişle kullanıcıların farklı kişisel özelliklerine, farklı öğrenme biçimlerine ve önbilgilere sahip olmaları, onların bu ortamı kullanırken öğrenme gereksinimlerinin farklılaşmasına neden olmaktadır. Harmanlanmış öğrenme ortamı kullananlar arasındaki farklılıkları dikkate alan ve her bir kullanıcının kişisel ihtiyaçlarına göre farklılaşan uyarlanabilir öğrenme ortamlarının tasarlanması ve geliştirilmesi olanaklı hale gelmiştir. (Brusilovsky, 2003).

Öğrencilerin öğrenme ortamındaki akademik başarılarını, performanslarını önemli ölçüde etkilediği düşünülen denetim odağı, öğrenme ortamının uyarlanması için göz önünde bulundurulabilir. Rotter tarafindan bireysel farklılıklar olarak tanımlanan denetim odağ1 pek çok durumda işlerlikte olan bir kişilik boyutu olarak ölçülüp değerlendirilebileceği kanıtlanmış ve bu yapı son 35 yılda kişilik araştırmalarının temel değişkenlerinden biri olmuştur (Rotter, 1966).

Denetim odağı, bireyleri etkisi altına alan olumlu veya olumsuz olayları, bireyler tarafından kendi davranışlarının sonucunda veya bu tip olayların şans, talih gibi dış etkenlerin etkisi olarak algılanma eğilimidir. (Rotter, 1966). Bireylerin kendi hal ve 
hareketlerinin sonucu olarak kişisel sorumluluğu kabul etme düzeyi olan denetim odağ1 içten ve diştan denetim olmak üzere iki kutupludur.

İçten denetimli bireyler kendilerini etkisi altına alan olaylarla ilgili olarak bu etmenlerin kendi denetimlerinde olduğuna inanırlar. Dıştan denetimli bireyler ise kendilerini etkisi altına alan olaylarla ilgili olarak bu etkilerin kendilerinin dişındaki etmenlerin denetiminde olduğuna inanırlar (Dönmez, 1986). İçten denetimli bireyler yaşantılarının sonuçlarında kendi davranışlarının etkili olduğu inancı hakimdir ve kendi yaşamlarını daha çok kendilerinin kontrol edebileceklerine inanırlar. Dıştan denetimli bireyler davranışlarının sonuçlarını ya da davranışlarının sonucunda gerçekleşen başarısızlarının kendisinden kaynaklanmadığını savunurlar (Wong Mc Donald, Gorsucu, 2004; Karahan, Sardoğan, Özkamal1, \& N. Dicle, 2005). K1sacas1, herhangi bir durum ile karşılaştığında karşılaştığ 1 durumun kendi davranışlarından kaynaklandığını kabul ediyorsa içten denetimli, fakat karşılaştığı durumun başka bireyler tarafindan olduğuna inanıyor veya şans, kader, talih olarak ifade ediyorsa dıştan denetimli olarak tanımlanmaktadır (Gardner \& Warren, 1978).

Harmanlanmış öğrenme ortamları öğrencilerin denetim odağı özelliklerini yansitabilecek şekilde uyarlanabilir. $\mathrm{Bu}$ nedenle harmanlanmış öğrenme ortamı öğrencilerin denetim odakları dikkate alınarak uyarlanırsa hem öğrencinin ilgisini çeker hem de öğrenciyi merkeze alır denilebilir. Yapılandırmacı yaklaşım özellikle öğrenciyi merkeze alan yaklaşımlardan biridir. Bu yaklaşımda öğrenci, öğrenmenin gerçekleşmesi için aktif olarak rol alır. Felsefe olarak başlayan, sosyoloji ve antropolojiye, daha sonra psikoloji ve eğitime uygulanan yapılandırmacılık, bilgi ve öğrenme ile ilgilidir (Hoşgörür, 2002). Yapılandırmacı yaklaşım, öğrencilere birtakım temel bilgi ve becerilerin kazandırılması gerektiği görüşünü inkâr etmez, fakat eğitimde bireylerin daha çok düşünmeyi, anlamayı, kendi öğrenmelerinden sorumlu olmayı ve kendi davranışlarını kontrol etmeyi öğrenmeleri gerektiğini vurgular (Saban, 2005).

Yapılandırmacı öğrenme yaklaşımın eğitimde kullanılmasına yönelik farklı modeller önerilmektedir. Bu modellerden biri de 5E öğrenme modelidir (Özmen, 2005). $5 \mathrm{E}$ öğrenme modeli yapılandırmacı yaklaşıma dayanır. 5E öğrenme modelinde özellikle öğrenciler tekrardan öğrenirler, düşünme imkanı bulurlar ve aynı zamanda öğrenciler kendileri ilk olarak ifade ettikleri kavram ve ifadeler üzerinde değişiklik ve düzenleme yapabilirler. Bunu hem çevreleriyle olan etkileşimleriyle hem sınıf aktiviteleriyle hem de deneyimleriyle yaparlar (Ergin, 2006).

5E öğrenme modeli, öğrencilerin verdikleri bilgileri dikkate alarak her aşamada öğrencilerin sadece farklı etkinlikler kazanmalarını değil, aynı zamanda kendi kavramlarını ve etkinliklerini de oluşturmalarına imkân sağlar (Martin, 2000). 5E öğrenme modeli RodgerBee tarafindan geliştirilmiştir. $\mathrm{Bu}$ model beş aşamadan oluşmaktadır. $\mathrm{Bu}$ aşamalar Giriş (Engage), Keşif (Explore), Açılama (Explain), Genişletme (Elaborate) ve Değerlendirme (Evaluate)' dir (Carin \& Bass, 2005). 5E öğrenme modeli öğrencilerin öğrenmenin değişik aşamaları ile bir konuya katılmalarına, dahil oldukları konu veya konuları araştırmalarına, tecrübelerinin arttırılmasına, öğrenmeleri ile ilgili daha derinlemesine bilgiye ulaşmalarına ve ulaştıkları bilgileri de değerlendirmeye yönlendirmektedir (Wilder \& Shuttleworth, 2005).

Fish (1999, s. 2), 5E öğrenme modeli ile ilgili bazı araştırmaları incelemiş ve şu sonuçlara ulaştığını belirtmiştir: 
$>$ Öğrenme için oldukça fazla başarı sağlar.

> Kavramların kalıcılık oranı oldukça yüksektir.

Bilime karşı olumlu tutum geliştirir.

Kıyas becerisinde gelişim sağlanır.

Bilimsel süreç becerilerinde gelişim sağlanır.

5E öğrenme modeli öğrenmeyi kolaylaştıran aynı zamanda öğrenme esnasında öğrenciye yararlı imkanlar oluşturan bir öğrenme döngüsüdür (Lorsbach, 2006).

Alanyazın incelendiğinde harmanlanmış öğrenme ortamında çalışmaların yapıldığı görülmüştür. Detaylı bir araştırma yapıldığında harmanlanmış öğrenme ortamında $5 \mathrm{E}$ öğrenme modelinin uygulandığına rastlanmamıştır. Yine alanyazın incelendiğinde öğrencilerin denetim odakları dikkat edilerek farklı ortamlarda farklı modeller kullanılarak çalışmalar yapıldığı görülmüştür. Fakat gerek harmanlamış ortamda gerekse 5E öğrenme modeli dikkate alınarak öğrencilerin denetim odaklarına göre gruplandırılarak bir çalışma yapıldığına rastlanmamıştır. 5E öğrenme modelinin harmanlanmış öğrenme ortamında uygulanabilirliğine dikkat çekmesi düşünülen bu çalışmada bir ilkin gerçekleştirmesi düşünülmektedir. Aynı zamanda algoritmanın öğretimi ile ilgili fazla bir araştırma yapılmadığı görülmüştür. Algoritma programlamanın öğretilmesinde bir temel teşkil etmektedir. Algoritma ne kadar iyi öğrenilirse öğrencilerin program yazma becerileri de o düzeyde gelişir. Algoritma öğretiminde genellikle geleneksel öğretim yöntemleri kullanılmaktadır. Farklı öğretim yöntemleri kullanılmadığı görülmüş̧ür. $\mathrm{Bu}$ nedenle algoritma öğretiminde farklı yöntemlerin kullanılması gerektiği görüşü öne çıkmaktadır. Bu araştırma ile öğrencilerin algoritmayı daha iyi anlamaları ve daha iyi algoritma geliştirebilecekleri düşünülmektedir. Algoritma, bilgisayardaki işlemlerin gerçekleştirilmesinde izlenecek adımlar dizisidir. Algoritma oluşturabilme ve yazabilme sıralı ve düzenli bir iştir. Algoritmayı düzgün bir şekilde anlamak için sistemli ve sıralı bir öğrenmenin gerçekleşmesi gerekir. 5E öğrenme modeli de sıralı ve aşamalı bir modeldir. 5E öğrenme modelinin her bir E' si, bir basamağı ifade eder ve bu basamaklarda siralı bir şekilde uygulanır. Algoritma yazmak sıralı bir süreç olduğu için aynı zamanda 5E öğrenme modeli de basamaklı bir öğrenme modeli olması nedeniyle algoritma öğretiminde $5 \mathrm{E}$ öğrenme modelinin etkili olacağı düşünülmektedir. Bu çalışma $5 \mathrm{E}$ öğrenme modelinin farklı ortamlarda öğrencilere nasıl bir etki sağlayacağı ve algoritma öğretiminde yer alan eksikliklerin giderilmesine katkı sağlayacak bulgulara ulaşmak için gerçekleştirilmiştir.

\section{Araştırmanın Amacı}

$\mathrm{Bu}$ araştırmada harmanlanmış öğrenme ortamında denetim odağına göre uyarlanmış 5E öğrenme modelinin öğrencilerin akademik başarılarına etkisini incelemeyi amaçlamaktadır. Bu genel amaç çerçevesinde aşağıdaki sorulara cevap aranmıştır.

1. Denetim odağına göre uyarlanmış $5 \mathrm{E}$ öğrenme modeline uygun harmanlanmış öğrenme ortamı ile harmanlanmış öğrenme ortamında ders alan;

a. Tüm grupların son test puanları arasında anlamlı bir fark var mıdır?

b. Deney grubu ve kontrol grubu öğrencilerinin son test puanları arasında anlamlı bir fark var midır? 
2. Denetim odağına göre uyarlanmış 5E öğrenme modeline uygun harmanlanmış öğrenme ortamı ile harmanlanmış öğrenme ortamında ders alan;

a. Tüm grupların kalıcılık testi puanları arasında anlamlı bir fark var mıdır?

b. Deney grubu ve kontrol grubu öğrencilerinin kalıcılık testi puanları arasında anlamlı bir fark var midır?

3. Denetim odağına göre uyarlanmış 5E öğrenme modeline uygun harmanlanmış öğrenme ortamında ders alan deney grubu öğrencilerinin son test - kalıcılık puanları arasında anlamlı bir fark var midır?

4. Denetim odağına göre uyarlanmış harmanlanmış öğrenme ortamında ders alan kontrol grubu öğrencilerinin son test - kalıcılık puanları arasında anlamlı bir fark var midir?

\section{Yöntem}

$\mathrm{Bu}$ bölümde araştırma modeli, araştırmaya katılan çalışma grubu, araştırmada kullanılan öğretim materyali açıklanmış, yararlanılan veri toplama araçları, deneysel işlemin uygulanması, verilerin toplanması, çözümlenmesi ve yorumlanması ile ilgili bilgiler verilmiştir.

\section{Araştırma Modeli}

5E öğrenme modeline uygun olarak denetim odağına göre uyarlanan harmanlanmış öğrenme ortamının öğrencilerin akademik başarısının incelenmesi amacıyla gerçekleştirilen bu araştırmada deneysel desen kullanılmıştır.

Araştırmanın bağımsız değişkeni denetim odağına uygun harmanlanmış öğrenme ortamıdır. Bağımsız değişkenin iki farklı düzeyi vardır. Bunlar; öğrencilerin denetim odağına göre uyarlanmış 5E öğrenme modeline uygun harmanlanmış öğrenme ortamı ve öğrencilerin denetim odağına uygun harmanlanmış öğrenme ortamıdır. Araştırmanın bağımlı değişkenleri ise öğrencilerin akademik başarılarıdır.

Araştırmada kullanılan deneysel modelin simgesel görünümü aşağıdaki gibidir.

Tablo 1

Araştırma Deseni

\begin{tabular}{ccccc}
\hline Gruplar & Ön Test & Deneysel İşlem & Son Test & $\begin{array}{c}\text { Kalıcıllk } \\
\text { Testi }\end{array}$ \\
\hline G1 R & $\mathrm{O}_{1.1}$ & Uygulama (Deney Grubu - İçten Denetimliler) & $\mathrm{O} 1_{1.2}$ & $\mathrm{O} 1_{1.3}$ \\
G2 R & $\mathrm{O} 1_{2.1}$ & Uygulama (Deney Grubu - Diştan Denetimliler) & $\mathrm{O} 1_{2.2}$ & $\mathrm{O} 1_{2.3}$ \\
G3 R & $\mathrm{O} 2_{1.1}$ & Uygulama (Kontrol Grubu - İçten Denetimliler) & $\mathrm{O} 2_{1.2}$ & $\mathrm{O} 2_{1.3}$ \\
G4 R & $\mathrm{O} 2_{2.1}$ & Uygulama (Kontrol Grubu - Diştan Denetimliler) & $\mathrm{O} 2_{2.1}$ & $\mathrm{O} 2_{2.3}$ \\
\hline
\end{tabular}

G1: İçten Denetim Odağına Sahip 5E Modeline Uygun Harmanlanmış Öğrenci Grubu.

G2: Dıştan Denetim Odağına Sahip 5E Modeline Uygun Harmanlanmış Öğrenci Grubu.

G3: İçten Denetim Odağına Sahip Harmanlanmış Öğrenci Grubu.

G4: Dıştan Denetim Odağına Sahip Harmanlanmış Öğrenci Grubu.

R: Yansız Atama

$\mathrm{O}_{1.1}, \mathrm{O}_{2.1}, \mathrm{O}_{1.1}$ ve $\mathrm{O}_{2.1:}$ Öğrencilerin öntest puanları

$\mathrm{O} 1_{1.2}, \mathrm{O}_{2.2}, \mathrm{O} 2_{1.2}$ ve $\mathrm{O} 2_{2.22}$ Öğrencilerin sontest puanları

$\mathrm{O}_{1.3}, \mathrm{O}_{2.3}, \mathrm{O} 2_{1.3}$ ve $\mathrm{O} 2_{2.3:}$ Öğrencilerin kalıcılık testi puanları 
Tablo 1'de görüldüğü gibi çalışmada dört farklı grup bulunmaktadır. Yansız atama ile iki gruba ayrılan öğrenciler denetim odağına göre uyarlanmış 5E öğrenme modeline uygun harmanlanmış öğrenme ortamına ve öğrencilerin denetim odağına uygun harmanlanmış öğrenme ortamına yerleştirilmiştir.

Hem deney hem de kontrol grubu için öğrencilerin denetim odağına göre uyarlama yapılmıştır. Bu uyarlama için içten denetimli ve diştan denetimli denetim odağı kullanılmıştır. Öğrencilerin hangi denetim odağına sahip olduğunun belirlenmesi için "Denetim Odağı Ölçeği” kullanılmıştır. Her iki öğrenme ortamıyla verilen eğitim sonrasında ölçmeden elde edilen sonuçlar, grup içi ve gruplar arası ilişkiler göz önüne alınarak değerlendirilmiştir.

\section{Katılımcilar}

Araştırma, 2011-2012 öğretim yılı Bozok Üniversitesi Meslek Yüksek Okulu Bilgisayar Teknolojileri Bölümü Bilgisayar Programcılığı öğrencilerinden oluşan ve birinci sınıf, birinci yarıyıl programında bulunan "Programlama Temelleri I" dersini alan 104 öğrenci üzerinde yürütülmüştür. Öğrencilerin tümüne Denetim Odağ1 Ölçeği uygulanarak bu ölçekten almış oldukları puanlara göre gruplar oluşturulmuştur.

Tablo 2

Uygulama İçin Oluşturulan Çalışma Grupları

\begin{tabular}{|c|c|c|c|c|}
\hline Grup & Alt Grup & KOÖ Sınırları & $\begin{array}{c}\text { Grup Öğrenci } \\
\text { Sayısı }\end{array}$ & Toplam \\
\hline \multirow{4}{*}{ Deney } & İçten Denetimli Grup & $2.95-0.41 / 2=2.75$ & & \multirow{8}{*}{104} \\
\hline & & $\bar{x} \leq 2.75$ & 26 & \\
\hline & Dıştan Denetimli Grup & $2.95+0.41 / 2=3.16$ & 7 & \\
\hline & & $\overline{\mathrm{x}} \geq 3.16$ & 21 & \\
\hline \multirow{4}{*}{ Kontrol } & İçten Denetimli Grup & $2.95-0.41 / 2=2.75$ & \multirow{2}{*}{25} & \\
\hline & \multirow{3}{*}{ Dıştan Denetimli Grup } & $\overline{\mathrm{x}} \leq 2.75$ & & \\
\hline & & $2.95+0.41 / 2=3.16$ & \multirow{2}{*}{26} & \\
\hline & & $\overline{\mathrm{x}} \geq 3.16$ & & \\
\hline
\end{tabular}

\section{Öğretim Materyali}

Algoritma konusunun öğretimine ilişkin uyarlanmış harmanlanmış öğrenme ortamı geliştirilmiştir. $\mathrm{Bu}$ öğrenme ortamı öğrencilerin denetim odağına göre uyarlanmış 5E öğrenme modeline uygun harmanlanmış öğrenme ortamı ve öğrencilerin denetim odağına uygun harmanlanmış öğrenme ortamı olmak üzere iki farklı biçimde tasarlanmıştır.

Her iki ortamda da bireylerin denetim odağı dikkate alınarak içten denetimli ve dıştan denetimli tasarım gerçekleştirilmiştir. Bu öğrenme ortamı, denetim odağı ile ilgili olarak literatür göz önünde bulundurularak içten denetimli ve diştan denetimli öğrencilerin özellikleri listelemiş ve bu özellikler dikkate alınarak gerçekleştirilmiştir.

Deney grubu için denetim odağına göre uyarlanmış 5E öğrenme modeline uygun harmanlanmış öğrenme ortamı tasarlanmıştır. Kontrol grubu için ise öğrencilerin denetim odağına uygun harmanlanmış öğrenme ortamı tasarlanmıştır. Öğrenme ortamı 
tasarlanırken öğrenme modelleri konusunda çalışmaları olan uzmanlar ile çevrimiçi ve harmanlanmış öğrenme ortamları konusunda çalışan alan uzmanlarından görüşler alınmıştır. Aynı zamanda öğrencilerin denetim odaklarına göre ortamlar tasarlanırken bu alanda çalışmaları olan uzmanlardan da görüş alınmıştır. Görüşler doğrultusunda ilgili çevrimiçi ve 5E öğrenme modeline uygun etkinlikler hazırlanmıştır. Aynı zamanda algoritma konusu ile ilgili ortama konulan örneklerin uygunluğu konusunda araştırma sürecinde birlikte çalışılan ve programlama konusunda deneyimli öğretim elemanlarından da görüşler alınmıştır. Uzmanlardan ve öğretim elemanlarından alınan görüşlere göre ortam ve içerikte gerekli olan düzenlemeler yapılmıştır.

Harmanlanmış öğrenme ortamında çevrimiçi etkinlikleri düzenlemek için MOODLE açık kaynak kodlu öğrenme yönetim sistemi kullanılmıştır. MOODLE, http://myo.bozok.edu.tr/programlama/ web sitesine kurulmuştur. Programlama Dilleri I dersi bu web sitesi üzerinden çevrimiçi olarak kullanıma açılmıştır.

Harmanlanmış öğrenme ortamında çevrimiçi öğrenme ortamları 5E öğrenme modeline uygun olarak, sohbet ortamlar1, konu anlatımı ve her bir haftanın sonunda sunulan alıştırma etkinliklerinden oluşmaktadır. Öğrenciler, çevrimiçi ortama kendilerine ait kullanıcı adı ve şifrelerini girerek erişmektedirler (Şekil 1)

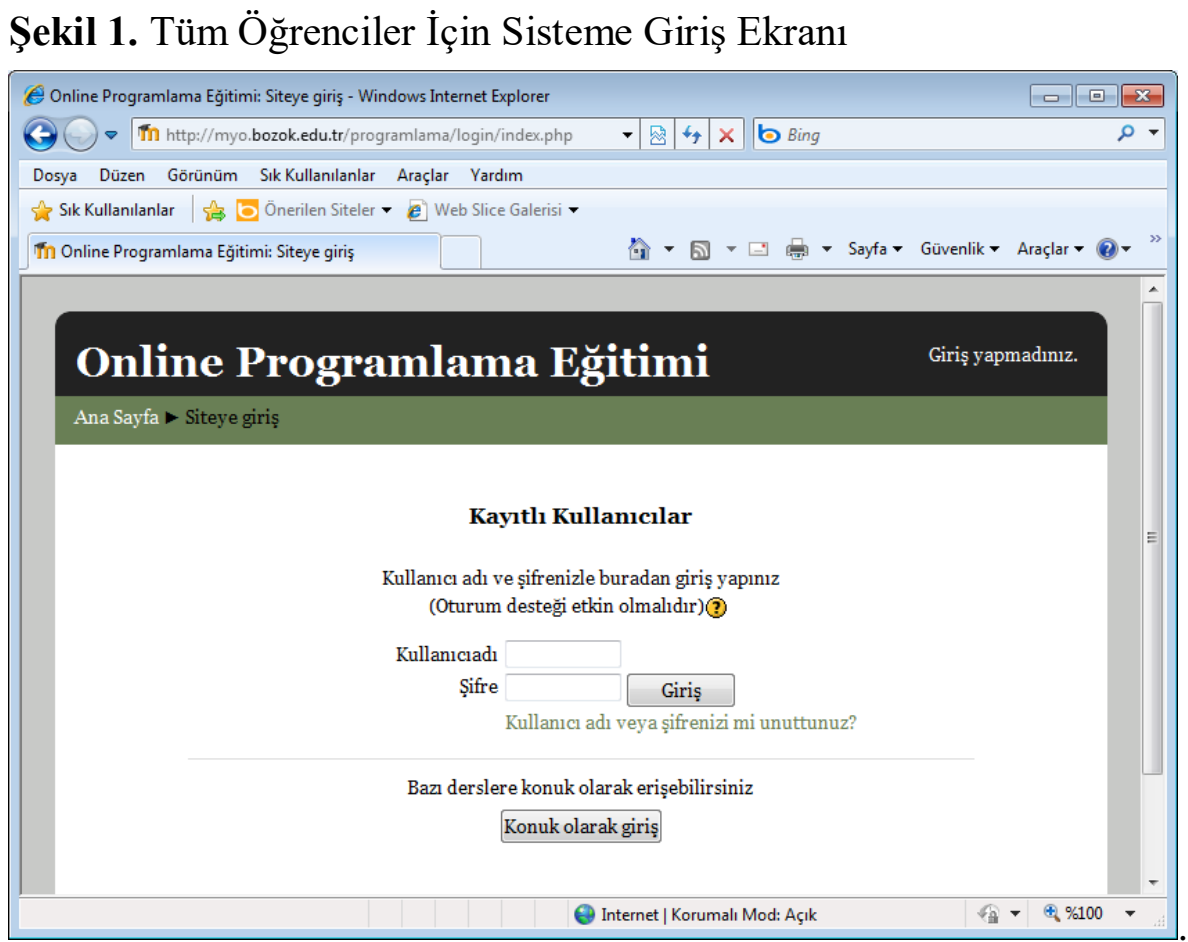

Hem deney hem de kontrol gruplarındaki öğrencilerin Harmanlanmış Öğrenme ortamında eğitim almaları sağlanmıştır. Fakat, deney gruplarına 5E öğrenme modeline uygun Harmanlamış Öğrenme ortamı hazırlanmış, kontrol gruplarına ise 5E öğrenme modelinden bağımsız Harmanlanmış Öğrenme ortamı hazırlanmıştır. Dıştan denetimli özelliklere sahip öğrenciler için açılan Deney grubu dersinin ismi Dişsal (A Grubu), içten denetimli özelliklere sahip öğrenciler için açılan Deney grubu dersinin ismi İçsel (B Grubu), dıştan denetimli özelliklere sahip öğrenciler için açılan Kontrol grubu dersinin ismi Dişsal (C Grubu), içten denetimli özelliklere sahip öğrenciler için açılan Deney grubu dersinin ismi İçsel (D Grubu) dur (Şekil 2). 
Şekil 2. Sistemin İlk Ekranı

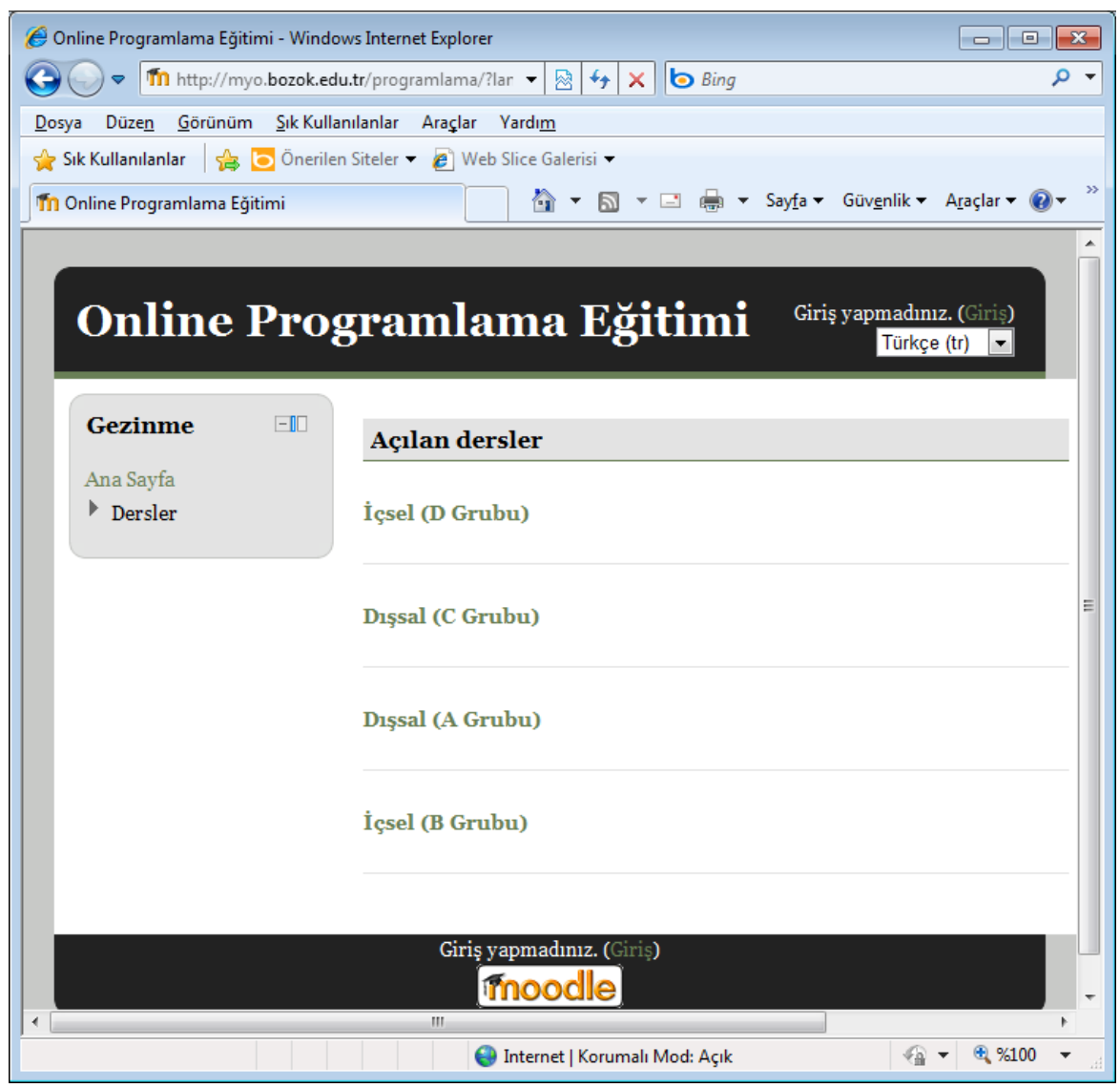

\section{Veri Toplama Araçları}

Verilerin toplanmasında öğrencilerin denetim odağını belirlemek amacıyla uygulamaya başlamadan önce "Denetim Odağı Ölçeğì" ve akademik başarı testi kullanılmıştır.

\section{Denetim Odağı Ölçeği}

Rotter (1966) tarafindan geliştirilen "Rotter' in İç-Dış Kontrol Odağı Ölçeği”" (RIDKOÖ) 29 maddeden oluşmaktadır. Bireylerin genellenmiş kontrol beklentilerinin, içsel denetimlilik-dışsal denetimlilik faktörü üzerindeki konumunu belirlemeyi amaçlamıştır. Dağ (1991), 1991 yılında bu ölçeği Türkçeye uyarlamıştır. Bu araştırma Hacettepe Üniversitesi öğrencilerinden iki ayrı örneklem üzerinde yapılmıştır. RIDKOÖ' nün bu çalışmadaki test-tekrar test güvenirlik katsayısı r=.83' tür. Ölçeğin güvenirlik katsayısı .68 ve Cronbach alfa iç tutarlılık katsayısı ise .70 olarak hesaplanmıştır. Öğrencilerin denetim odaklarını belirlemek için araştırmada "Denetim Odağı Ölçeği” kullanılmıştır.

Dağ (2002) tarafindan 'Rotter' in İç-D1ş Kontrol Odağı Ölçeğii” (RİDKOÖ)' den daha kapsamlı ve Likert formatında yeni bir kontrol odağı ölçeği geliştirmiştir. Bu ölçeği geliştirmek için önce çeşitli kontrol odağı ölçeklerinden aynen yada değiştirilerek alınmış ve olası kontrol alanlarını büyük ölçüde kapsayan 80 maddelik bir madde havuzu oluşturmuştur. Yapılan analizlersonucunda 47 maddeden oluşan form Kontrol Odağı Ölçeği (KOÖ) ismini almıştır. Elde edilen 47 maddelik Kontrol Odağı Ölçeği (KOÖ)' nin iç tutarlılık katsayısı Cronbach alfa=.92 olarak bulunmuştur. Aynı zamanda ölçeğin her bir maddesi için madde bırakma tekniği ile madde-toplam korelasyonu da hesaplanmıştır. $\mathrm{Bu}$ korelasyonların ortalaması .45 olmak üzere .20 ile .70 arasında 
değiştiği görülmüştür. Ölçeğin 1 ay arayla tekrar uygulanmasıyla elde edilen veriler üzerinden hesaplanan test tekrar test güvenirlik katsayısı ise Pearson $\mathrm{r}=.88^{\prime} \mathrm{dir}(\mathrm{sd}=$ 89; $\mathrm{p}$ <.0001). Ölçeğin alt ölçeklerinin test tekrar test güvenirlik katsayıları ise sırasıyla, $.83, .81, .61, .89$ ve. 74 olarak bulunmuştur.

Kontrol Odağı Ölçeği (KOÖ), gerek faktör yapısıyla gerek aynı alanda ölçüm yapan Rotter' in İç-Dış Kontrol Odağı Ölçeği” (RİDKOÖ) puanlarıyla \%45' lik bir varyansı paylaşmasıyla kontrol odağını Türkçe' de ve kültürümüzde geçerli olarak ölçen bir ölçek sonucuna varılabilir (Dağ, 2002). Öğrencilerin denetim odaklarını belirlemek için araştırmada "Denetim Odağı Ölçeği” kullanılmıştır.

\section{Akademik Başarı Testi}

Araştırmada öğrencilerin ön bilgi düzeylerini ve deneysel işlem sonrasında akademik başarılarını ölçmek için açık uçlu olarak geliştirilen başarı testi kullanılmıştır. $\mathrm{Bu}$ başarı testi hazırlanırken beş ayrı uzmanın görüşlerinden faydalanılmıştır. Araştırmada öğrencilere uygulanan başarı testi Bloom' un bilişsel alan taksonomisi ve belirtke tablosu dikkate alınarak geliştirilmiş, hem denetim odağına göre uyarlanmış $5 \mathrm{E}$ öğrenme modeline uygun harmanlanmış öğrenme grubu hem de denetim odağına göre uyarlanmış harmanlanmış öğrenme grubu öğrencilerine uygulanmıştır. Başarı testi ölçme aracındaki sorular Bloom' un bilişsel alan taksonomisine göre puanlanmıştır.

Uzman değerlendirilmesi sonucunda gerekli düzenlemeler yapılarak sorulara son şekli verilmiştir. Hazırlanan aynı test öntest ve sontest olarak uygulanmıştır. Öntest uygulama öncesinde uygulanarak değerlendirme formuna göre puanlanmıştır. Uygulama bittikten sonra ise aynı test öğrencilerin akademik başarılarını ölçmek amacıyla son test olarak uygulanmış ve değerlendirilmiştir. Sontest ile değerlendirme yapıldıktan bir ay sonra öğrencilerin öğrendikleri bilgilerin kalıcı hale gelip gelmediğini ölçmek için Kalıcılık testi uygulanmıştır. Hem ön test - son test hem de kalıcılık testi için elde edilen verilerin güvenirliğini sağlamak amacıyla cevaplar iki konu alanı uzmanı tarafından puanlanmış ve bağımsız puanlayıcılar arası korelasyon katsayısı hesaplanmıştır.

Açık uçlu sorular 100 puan üzerinden değerlendirilmiştir. İki uzman puanlayıcının verdiği puanlar birbirleriyle uyumlu bulunmuştur. Bir puanlayıcının yüksek puan verdiği bir öğrenciye diğer puanlayıcı da yüksek; düşük puan verdiği bir öğrenciye diğer puanlayıcı da düşük puan vermiştir. Bu bağlamda iki puanlayıcının verdiği puanların aritmetik ortalamaları alınmıştır.

\section{Uygulama Süreci}

Deney grubunda uygulama beş hafta boyunca devam etmiştir. Beş hafta boyunca öğrencilerle her hafta 5E öğrenme modelinin bir $\mathrm{E}$ aşaması gerçekleştirilmiştir. 1E (Giriş) aşamasında öğrencilerle uygulamaya giriş yapılmıştır. 2E (Keşfetme) aşamasında öğrencilere konu keşfettirilmeye çalışılmış ve algoritmalarla ilgili temel örnekler üzerinde tartışmalar gerçekleştirilmiştir. 3E (Açıklama) aşaması sınıf ortamında gerçekleştirilmiştir. Bu aşamada ise bir önceki aşamadan elde edilen sonuçlar doğrultusunda algoritma üzerinde açıklamalar ve konu anlatımı gerçekleştirilmiştir. 4E (Genişletme) aşamasında algoritma ile ilgili daha derin ileri örnekler üzerinde tartışılmıştır. Son aşamada, bir başka deyişle 5E (Değerlendirme) aşamasında gruplara uygun değerlendirmeler yapılmıştır. Özellikle deney grubundaki öğrencilerin aşamalar 
sonucunda etkinlikleri yapabilmeleri için bilgisayar laboratuvarı öğrencilere tedarik edilmiştir.

Kontrol grubu öğrencilerine ise harmanlanmış öğrenme ortamına uygun olarak hem çevrimiçi ortamda hem de sınıf ortamında konu anlatılmıştır. Kontrol grubu öğrencileri için evden internete bağlanması mümkün olmayan öğrenciler göz önünde bulundurularak her biri 35 bilgisayardan oluşan iki bilgisayar laboratuarı haftada iki gün ve toplamda 5 saat olarak öğrencilerin kullanımına açılmıştır.

Her iki gruba da uygulamaya başlamadan önce araştırmacı ve dersin öğretim elemanı tarafindan öğrenme ortamı ile ilgili ortama nasıl girebilecekleri ortamı nasıl kullanabilecekleri gibi bilgiler verilmiş, ortam menüleri, yardımı ve diğer araçları nasıl kullanacakları, ders ortamında nasıl davranacakları ve uyacakları kurallar tanıtılmıştır.

Deney grubundaki öğrenciler ile uygulamalar ders saati içinde gerçekleştirilmiştir. Öğrencilerin dersin sonunda verilen ödevleri yapabilmeleri ve dersin öğretim elemanına gönderebilmeleri için 30 adet bilgisayardan oluşan bir adet bilgisayar laboratuarı haftada bir gün toplamda 2 saat olarak öğrencilerin kullanımına açılmıştır.

\section{Verilerin Analizi}

$5 \mathrm{E}$ öğrenme modeline göre harmanlanmış öğrenme ile geleneksel harmanlanmış öğrenmenin öğrencilerin akademik başarılarına ve kalıcılı̆̆ına etkisini belirlemek amacıyla t-testi ve tek faktörlü kovaryans analizi (ANCOVA) kullanılmıştır.

\section{Bulgular ve Yorumlar}

$\mathrm{Bu}$ bölümde, 5E modeline uygun olarak denetim odağına göre uyarlanan harmanlanmış öğrenme ortamının öğrencilerin akademik başarısına ilişkin bulgular ve yorumlar sunulmaktadır.

\section{Tüm Grupların Ön Test Puanlarına İlişkin Bulgular}

Yapılan denkleştirme işlemi sonucunda deney ve kontrol gruplarına göre denetim odaklarına ilişkin öğrencilerin akademik başarı öntest puanları arasında istatistiksel olarak anlamlı bir farklılık olup olmadığını test etmek amacıyla ilişkisiz örneklemler için tek faktörlü varyans analizi kullanılmıştır. Analiz sonuçları Tablo 3' de yer almaktadır.

Tablo 3

Tüm Grupların Öntest Puanlarına İlişkin İstatistik Sonuçları

\begin{tabular}{llllll}
\hline Varyansın Kaynağı & Kareler Toplamı & $S d$ & $\begin{array}{l}\text { Kareler } \\
\text { Ortalaması }\end{array}$ & $F$ & $p$ \\
\hline Gruplararası & 375.225 & 3 & 93.625 & & \\
Gruplariçi & 7110.253 & 100 & 75.457 & & .160 \\
Toplam & 7485.478 & 103 & & \\
\hline
\end{tabular}

Yapılan tek yönlü varyans analizi sonuçlarına bakıldığında deney ve kontrol gruplarındaki denetim odağı farklı öğrencilerin öntest puanları arasında anlamlı bir fark 
olmadığ 1 tespit edilmiştir $\left(F_{(3-100)}=1.759, p>.05\right)$. Bir başka deyişle bu grupların akademik başarı öntest puanları açısından istatistiksel olarak birbirine denk olduğu söylenebilir.

\section{Tüm Grupların Son Test Puanlarına İlişkin Bulgular}

Yapılan deneysel çalışma sonucunda deney ve kontrol gruplarına göre denetim odaklarına ilişkin öğrencilerin akademik başarı sontest puanları arasında istatistiksel olarak anlamlı bir farklılık olup olmadığını test etmek amacıyla ilişkisiz örneklemler için tek faktörlü varyans analizi kullanılmıştır. Analiz sonuçları Tablo ' 4 de yer almaktadır.

Tablo 4

Tüm Grupların Sontest Puanlarına İlişkin Betimsel İstatistik Sonuçları

\begin{tabular}{llllll}
\hline $\begin{array}{l}\text { Varyansın } \\
\text { Kaynağı }\end{array}$ & Kareler Toplamı & $S d$ & $\begin{array}{l}\text { Kareler } \\
\text { Ortalaması }\end{array}$ & $F$ & $p$ \\
\hline Gruplararası & 3548.593 & 3 & 1182.864 & 5.487 & .002 \\
\hline Gruplariçi & 21556.946 & 100 & 215.569 & & \\
\hline Toplam & 25105.538 & 103 & & \\
\hline
\end{tabular}

Yapılan tek yönlü varyans analizi sonuçlarına bakıldığında deney ve kontrol gruplarındaki denetim odağı farklı öğrencilerin sontest puanları arasında anlamlı bir fark olduğu tespit edilmiştir $\left(F_{(3-100)}=5.487, p<.01\right)$. Bir başka deyişle bu grupların akademik başarı sontest puanları her iki gruptaki denetim odağı farklı öğrencilere bağlı olarak anlamlı bir şekilde değişmektedir. Sontestler arasındaki farklılıkların hangi gruplar arasında olduğunu bulmak amacıyla yapılan Scheffe testinin sonuçlarına göre, deney grubundaki dıştan denetim odağına sahip öğrencilerin $(\bar{x}=66.72)$, deney grubundaki içten denetim odağına sahip öğrencilerden $(\bar{x}=56.23)$, kontrol grubundaki dıştan denetim odağına sahip öğrencilerden $(\bar{x}=55.06)$ ve kontrol grubundaki içten denetim odağına sahip öğrencilerden $(\bar{x}=51.00)$ daha anlamlı olduğu belirlenmiştir.

$\mathrm{Bu}$ sonuca göre, harmanlanmış öğrenme ortamında $5 \mathrm{E}$ öğrenme modelinin deney grubundaki dıştan denetimli öğrencilerin hem deney grubundaki içten denetimli öğrencilere göre hem de kontrol grubundaki diğer öğrencilere göre algoritma konusunun öğrenilmesinde anlamlı bir fark oluşturacak ölçüde etkiye sahip olduğu söylenebilir.

\section{Bulgular}

\section{Deney ve Kontrol Grubu Öğrencilerinin Son Test Puanlarına İlişkin}

Yapılan deneysel çalışma sonucunda deney ve kontrol gruplarına göre öğrencilerin akademik başarı sontest puanları arasında anlamlı düzeyde farklılık olup olmadığına ilişkin bulgular aşağıda verilmiştir.

Deney ve Kontrol gruplarına uygulanan son test akademik başarı puanlarının ön teste göre düzeltilmiş puan ortalamaları Tablo 4' de verilmiştir. 
Tablo 4

Deney ve Kontrol Grubunun Düzeltilmiş Sontest Akademik Başarı Puanlarına İlişkin Betimsel Ístatistik Sonuçları

\begin{tabular}{llll}
\hline Grup & $N$ & $\bar{x}$ & $\bar{x}$ (Düzeltilmiş) \\
\hline Deney & 53 & 61.58 & 61.15 \\
Kontrol & 51 & 53.07 & 53.52 \\
\hline
\end{tabular}

Tablo 4' de görüldüğü gibi, deney ortamında öğrenim gören öğrencilerin son test puanları $(\overline{\mathrm{x}}=61.58)$, kontrol ortamında öğrenim gören öğrencilerin son test puanlarına $(\overline{\mathrm{x}}=53.07)$ göre daha yüksek çıkmıştır. $\mathrm{Bu}$ bulguya göre, harmanlanmış öğrenme ortamında 5E modelinin deney grubundaki öğrencilerin kontrol grubundaki öğrencilere göre algoritma konusunun öğrenilmesinde anlamlı bir fark oluşturacak ölçüde etkiye sahip olduğu söylenebilir. Ancak, grupların akademik başarı testi düzeltilmiş ortalamaları hesaplandığında, deney grubunun son test ortalaması 61.15, kontrol grubunun son test ortalaması ise 53.52 olarak gerçekleşmiştir. Her iki grubun düzeltilmiş son test akademik başarı puan ortalamaları arasında anlamlı düzeyde farklılık olup olmadığını belirlemek için ANCOVA testi yapılmış ve sonuçları Tablo 5' de gösterilmiştir.

Tablo 5

Deney ve Kontrol Grubunun Düzeltilmiş Sontest Akademik Başarl Puanlarl Kovaryans Analizi Sonuçları

\begin{tabular}{llllll}
\hline $\begin{array}{l}\text { Varyansın } \\
\text { Kaynağı }\end{array}$ & $\begin{array}{l}\text { Kareler } \\
\text { Toplamı }\end{array}$ & $S d$ & $\begin{array}{l}\text { Kareler } \\
\text { Ortalamas }\end{array}$ & $F$ & $p$ \\
\hline Öntest & 2375.672 & 1 & 2375.672 & 11.310 & .001 \\
5E/5E' siz & 1499.750 & 1 & 1499.750 & 7.265 & .008 \\
Hata & 20849.036 & 101 & 206.426 & & \\
Toplam & 25105.538 & 103 & & & \\
\hline
\end{tabular}

Tablo 5' deki Kovaryans analizi sonuçları incelendiğinde, 5E öğrenme modeline göre harmanlanmış öğrenme ortamı ile 5E' siz harmanlanmış öğrenme ortamında ders gören grupların düzeltilmiş son test başarı akademik başarı ortalama puanları arasında anlamlı düzeyde farklılık çıkmıştır $\left(F_{(1-101)}=7.265, p<.05\right)$. Ortaya çıkan farklılık, 5E öğrenme modeline göre hazırlanmış harmanlanmış öğrenme ortamında ders alan öğrenciler son test akademik başarı puanları 5E öğrenme modeli kullanılmayan harmanlanmış öğrenme ortamında ders alan öğrencilerden daha başarılı oldukları şeklinde değerlendirilebilir. 


\section{Tüm Grupların Kalıcılık Testi Puanlarına İlişkin Bulgular}

Yapılan deneysel çalışma sonucunda deney ve kontrol gruplarına göre denetim odaklarına ilişkin öğrencilerin akademik başarı kalıcılık puanları arasında istatistiksel olarak anlamlı bir farklılık olup olmadığını test etmek amacıyla ilişkisiz örneklemler için tek faktörlü varyans analizi kullanılmıştır. Analiz sonuçları Tablo 6' da yer almaktadır.

Tablo 6

Tüm Grupların Kalıcılık Testi Akademik Başarı Puanlarına İlişkin Betimsel İstatistik Sonuçları

\begin{tabular}{llllll}
\hline $\begin{array}{l}\text { Varyansın } \\
\text { Kaynağı }\end{array}$ & Kareler Toplamı & $S d$ & $\begin{array}{l}\text { Kareler } \\
\text { Ortalaması }\end{array}$ & $F$ & $p$ \\
\hline Gruplararası & 2873.620 & 3 & 957.873 & & \\
Gruplariçi & 17226.255 & 100 & 172.263 & 5.561 & .001 \\
Toplam & 20099.875 & 103 & & & \\
\hline
\end{tabular}

Yapılan tek yönlü varyans analizi sonuçlarına bakıldığında deney ve kontrol gruplarındaki denetim odağı farklı öğrencilerin kalıcılık testi puanları arasında anlamlı bir fark olduğu tespit edilmiştir $\left(F_{(3-100)}=5.561, p<.01\right)$. Bir başka deyişle bu grupların akademik başarı kalıcılık testi puanları her iki gruptaki denetim odağı farklı öğrencilere bağlı olarak anlamlı bir şekilde değişmektedir. Kalıcılık testler arasındaki farklılıkların hangi gruplar arasında olduğunu bulmak amacıyla yapılan Scheffe testinin sonuçlarına göre, deney grubundaki dışsal denetim odağına sahip öğrencilerin $(\bar{x}=67.90)$, deney grubundaki içsel denetim odağına sahip öğrencilerden $(\bar{x}=57.60)$, kontrol grubundaki dışsal denetim odağına sahip öğrencilerden $(\bar{x}=54.12)$ ve kontrol grubundaki içsel denetim odağına sahip öğrencilerden $(\bar{x}=54.48)$ daha anlamlı olduğu belirlenmiştir.

$\mathrm{Bu}$ sonuca göre, harmanlanmış öğrenme ortamında $5 \mathrm{E}$ öğrenme modelinin deney grubundaki diştan denetimli öğrencilerin, hem deney grubundaki içten denetimli öğrencilere göre hemde kontrol grubundaki öğrencilere göre algoritma konusunun daha kalıcı düzeyde öğrenilmesinde anlamlı bir fark oluşturacak ölçüde etkiye sahip olduğu söylenebilir.

\section{Deney Grubu ve Kontrol Grubu Öğrencilerinin Kalıcılık Testi Puanlarına İlişkin Bulgular}

Yapılan deneysel çalışma sonucunda deney ve kontrol gruplarına göre öğrencilerin akademik başarı kalıcılık testi puanları arasında anlamlı düzeyde farklılık olup olmadığına ilişkin bulgular aşağıda verilmiştir.

Deney ve Kontrol gruplarına uygulanan kalıcılık testi akademik başarı puanlarının ön teste göre düzeltilmiş puan ortalamaları Tablo 7' de verilmiştir. 
Tablo 7

Deney ve Kontrol Grubunun Düzeltilmiş Kalıcılık Akademik Başarı Puanlarına İlişkin Betimsel İstatistik Sonuçları

\begin{tabular}{llll}
\hline Grup & $\mathrm{N}$ & $\overline{\mathrm{x}}$ & $\overline{\mathrm{x}}$ (Düzeltilmiş) \\
\hline Deney & 53 & 62.02 & 61.79 \\
Kontrol & 51 & 55.10 & 55.34 \\
\hline
\end{tabular}

Tablo 7'de görüldüğü gibi, deney ortamında öğrenim gören öğrencilerin kalıcılık testi puanları $(\bar{x}=62.02)$, kontrol ortamında $(\bar{x}=55.10)$ öğrenim gören öğrencilerin kalıcılık puanlarına göre daha yüksek çıkmıştır. Bu bulguya göre, harmanlanmış öğrenme ortamında 5E öğrenme modelinin deney grubundaki öğrencilerin kontrol grubundaki öğrencilere göre algoritma konusunun kalıcı olarak öğrenilmesinde anlamlı bir fark oluşturacak ölçüde etkiye sahip olduğu söylenebilir. Fakat, deney ve kontrol gruplarının akademik başarı testi düzeltilmiş ortalamaları hesaplandığında, deney grubunun kalıc1lık testi ortalaması 61.79, kontrol grubunun kalıc1lı testi ortalamas1 ise 55.34 olarak gerçekleşmiştir. Deney ve kontrol grubunun düzeltilmiş kalıcılık testi akademik başarı puan ortalamaları arasında anlamlı düzeyde farklılık olup olmadığını belirlemek için ANCOVA testi uygulanmış ve sonuçları Tablo 8' de gösterilmiştir.

Tablo 8

Deney ve Kontrol Grubunun Öntest Puanlarına Göre Düzeltilmiş Kalıcılık Akademik Başarı Puanları Kovaryans Analizi Sonuçları

\begin{tabular}{llllll}
\hline $\begin{array}{l}\text { Varyansın } \\
\text { Kaynağ } 1\end{array}$ & $\begin{array}{l}\text { Kareler } \\
\text { Toplamı }\end{array}$ & $S d$ & $\begin{array}{l}\text { Kareler } \\
\text { Ortalamas } 1\end{array}$ & $F$ & $p$ \\
\hline Öntest & 685.880 & 1 & 685.880 & 3.813 & .054 \\
5E/5E' siz & 1071.807 & 1 & 1071.807 & 5.958 & .016 \\
Hata & 18169.110 & 101 & 179.892 & & \\
Toplam & 20099.875 & 103 & & & \\
\hline
\end{tabular}

Tablo 8'deki Kovaryans analizi sonuçları incelendiğinde, 5E öğrenme modeline göre harmanlanmış öğrenme ortamı ile 5E' siz harmanlanmış öğrenme ortamında ders gören grupların düzeltilmiş kalıcılık testi akademik başarı ortalama puanları arasında anlamlı düzeyde farklılık çıkmıştır $\left(F_{(1-101)}=5.958, p<.05\right)$. Ortaya çıkan farklılık, 5E öğrenme modeline göre hazırlanmış harmanlanmış öğrenme ortamında ders alan öğrencilerin kalıcılık test akademik başarı puanları 5E öğrenme modeli kullanılmayan harmanlanmış öğrenme ortamında ders alan öğrencilerden daha başarılı oldukları şeklinde değerlendirilebilir. 


\section{Bulgular}

Deney Grubu Öğrencilerinin Son Test - Kalıcılık Testi Puanlarına İlişkin

Deney grubu öğrencilerinin son test- kalıcılık testi puanları Tablo 9' de verilmektedir.

Tablo 9

Deney Grubunun Sontest ve Kalıcılık Testi Puanlarına İlişkin t-testi Karşılaştırması

\begin{tabular}{lcccccc}
\hline Grup & $N$ & $\overline{\mathrm{x}}$ & $S s$ & $S d$ & $\mathrm{t}$ & $p$ \\
\hline Son test & 53 & 61.58 & 13.06 & 52 & -.268 & .790 \\
Kalıcllk Testi & 53 & 62.02 & 11.20 & & & \\
\hline
\end{tabular}

Tablo 9 incelendiğinde, deney grubu öğrencilerinin son test - kalıcılık testi puan ortalamaları arasındaki fark anlamlı bulunmamıştır $\left[t_{(52)}=-.268, p>.05\right]$. Deney grubundaki öğrencilerin son test puan ortalamaları 61.58 iken, kalıcılık testi puan ortalamaları 62.02' ye çıkmıştır. Buna göre, deney grubundaki öğrencilerin daha kalıcı öğrenme gerçekleştirdikleri ve gerek çevrimiçi ortamda gerekse sınıf ortamında yapılan etkinlikler nedeniyle öğrendiklerini daha uzun süre hafizlarında tuttukları söylenebilir.

\section{Bulgular}

Kontrol Grubu Öğrencilerinin Son Test - Kalıcılık Testi Puanlarına İlişsin

Kontrol grubu öğrencilerinin son test-kalıcılık puanları Tablo 10' da verilmektedir.

Tablo 10

Kontrol Grubunun Sontest ve Kalıcılık Testi Puanlarına İlişkin t-testi Karşılaştırması

\begin{tabular}{lcccccc}
\hline Grup & $N$ & $\overline{\mathrm{x}}$ & $S s$ & $S d$ & $t$ & $p$ \\
\hline Son test & 51 & 53.07 & 16.94 & 50 & -.911 & .367 \\
Kalıcllik Testi & 51 & 55.10 & 15.71 & & & \\
\hline
\end{tabular}

Tablo 10 incelendiğinde, kontrol grubu ögrencilerinin son test - kalıcılık testi puan ortalamaları arasındaki fark anlamlı bulunmamıştır $\left[t_{(50)}=-.911, p>.05\right]$. Öğrencilerin son test puan ortalamaları 53.07 iken, kalıcılık testi puan ortalamaları 55.10' a çıkmıştır. Buna göre, kontrol grubundaki öğrencilerin daha kalıcı öğrenme gerçekleştirdikleri, çevrimiçi ortamda kendilerine sunulan dersi ve örnekleri istedikleri zaman tekrar edebilme, aynı zamanda da öğrendiklerini sınıf ortamında arkadaşlarıyla tekrar edebilmeleri nedeniyle öğrendiklerini daha uzun süre hafizalarında tuttukları söylenebilir.

\section{Sonuç ve Öneriler}

$\mathrm{Bu}$ araştırmanın sonucunda 5E öğrenme modeline uygun olarak denetim odağına göre uyarlanan harmanlanmış öğrenme ortamında ders alan öğrencilerin 5E öğrenme modeli kullanılmayan denetim odağına göre uyarlanan harmanlanmış öğrenme 
ortamında ders alan öğrencilere nazaran akademik açıdan daha başarılı oldukları ve bu öğrenmelerinin daha kalıcı olduğu görülmüştür. Araştırmanın problemleri ve alt problemlerine göre elde edilen sonuçlar aşağıda verilmiştir.

Tüm grupların son test akademik başarı puanları arasında anlamlı bir fark bulunmuştur. Son testler arasında deney grubundaki diştan denetim odağına sahip öğrencilerin diğer gruplara göre akademik başarı puanları daha yüksek bulunmuştur. $\mathrm{Bu}$ sonuca göre diştan denetim odağına sahip deney grubu öğrencileri için 5E öğrenme modeline göre harmanlanmış öğrenme ortamının akademik başarıyı yükseltme açısından daha etkili olduğu sonucuna ulaşılabilir. Programlamada insanların özellikle de günlük hayatlarında yaptığı "plan” kavramına karşılık olarak "algoritma" kavramı vardır. Bilgisayardaki ve programlamadaki işlemlerin gerçekleştirilmesinde izlenecek adımlar dizisine de algoritma denir. Bir başka deyişle algoritma, problemleri çözdürebilmek, kontrolleri gerçekleştirebilmek gibi işlemleri yaptırabilmek için bilgisayara iletilen işlem basamaklarıdır. Algoritma oluşturabilme veya yazabilme sıralı veya düzenli bir iştir. Algoritmayı düzgün bir şekilde anlamak için ne kadar sistemli ve sıralı halde anlamak gerekirse dıştan denetim odağına sahip bireylerde sıralı, düzenli ve disiplinli öğrenmeyi daha çok benimserler. Dıştan denetimli bireyler olaylar karşısında daha fazla bağımlı ve daha pasif davranış eğilimindedirler (Kağıtçıbaşı, 1972). Dıştan denetimli bireylerin problem çözme durumlarında daha çok kendilerinden isteneni yerine getirmeye çalışan bireyler olduğu ortaya çıkmıştır (Pines \& Julian, 1972). Algoritma sıralı, aşamalı bir süreçtir. Algoritma yazarken bir adımın atlanması programın doğru çalışmamasına neden olur. $\mathrm{Bu}$ nedenle de diştan denetim odağına sahip bireylerin algoritma yazımında veya öğretiminde daha başarılı olduğu söylenebilir.

Harmanlanmış öğrenme ortamında denetim odağına göre uyarlanmış $5 \mathrm{E}$ öğrenme modeline uygun eğitim alan deney grubu ve harmanlanmış öğrenme ortamında eğitim alan kontrol grubu öğrencilerinin son test akademik başarı puanları arasında anlamlı bir fark bulunmuştur. Başka bir deyişle deney grubu öğrencilerinin son test başarı puanları kontrol grubu öğrencilerinin son test başarı puanlarına göre daha yüksek bulunmuştur. $\mathrm{Bu}$ sonuca göre algoritma konusunun öğrenilmesinde 5E öğrenme modelinin daha etkili olduğu sonucuna ulaşılabilir. Öztürk (2008) tarafından yapılan araştırma sonucunda da yapılandırmacı yaklaşıma dayalı 5E öğrenme modelinin kullanıldığ grupta akademik başarının geleneksel öğretimin yürütüldüğü gruba göre daha yüksek çıktığı bulunmuştur. Hançer (2005) tarafından yapılan araştırma sonucuna bakıldığında yapılandırmacı yaklaşıma dayalı 5E öğrenme modeli kullanılarak uygulanan bilgisayar destekli öğrenme yönteminin öğrencilerin akademik başarı düzeylerini arttırdığı sonucuna ulaşılmıştır. Ergin (2006) tarafindan yapılan araştırma sonucunda yapılandırmacı yaklaşıma dayalı $5 \mathrm{E}$ modelinin kullanıldığ 1 grupta akademik başarının geleneksel öğretimin yürütüldüğü gruba göre daha yüksek çıktı̆̆1 bulunmuştur. Newby (2004), “Genç Öğrencileri Fene Yakınlaştırmak İçin Araştırmayı Kullanma" adlı araştırmasında 5E Modeline uygun uygulamalar yapmıştır. Araştırmasının sonucunda fen öğretiminde öğrencilerin kendilerini daha rahat hissettiklerinde ve deneysel etkinlikler derslere uygun bir şekilde entegre edildiğinde öğrenci başarısının yükseldiği sonucuna ulaşmıştır. Yukarıda verilen 5E öğrenme modeli ile ilgili araştırmaların sonuçları incelendiğinde yapılan bu araştırmanın bulgularını destekler nitelikte olduğu görülmektedir. Bir başka deyişle yapılan bu 
araştırma bulgularının da göstermiş olduğu gibi 5E öğrenme modeli ile ders alan öğrencilerin yüksek akademik başarı elde ettiği söylenebilir.

Tüm grupların kalıcılık testi akademik başarı puanları arasında anlamlı bir fark bulunmuştur. Kalıcılık test sonuçları arasında deney grubundaki dıştan denetim odağına sahip öğrencilerin diğer gruplara göre akademik kalıcılık testi sonuçları daha yüksek bulunmuştur. Bu sonuca göre dıştan denetim odağına sahip deney grubu öğrencileri için $5 \mathrm{E}$ öğrenme modeline göre harmanlanmış öğrenme ortamının akademik başarıyı daha kalıcı hale getirdiği sonucuna ulaşılabilir.

Denetim odağına göre uyarlanmış $5 \mathrm{E}$ öğrenme modeline uygun harmanlanmış öğrenme ortamında eğitim alan deney grubu ve harmanlanmış öğrenme ortamında eğitim alan kontrol grubu öğrencilerinin kalıcılık testi akademik başarı puanları arasında anlamlı bir fark bulunmuştur. Başka bir deyişle deney grubu öğrencilerinin kalıcılık testi başarı puanları kontrol grubu öğrencilerinin kalıcılık testi başarı puanlarına göre daha yüksek bulunmuştur. $\mathrm{Bu}$ sonuca göre, harmanlanmış öğrenme ortamında $5 \mathrm{E}$ öğrenme modelinin algoritma konusunun daha kalıcı öğrenilmesine neden olduğu sonucuna ulaşılabilir.

Denetim odağına göre uyarlanmış 5E öğrenme modeline uygun harmanlanmış öğrenme ortamında eğitim alan deney grubu öğrencilerin son test - kalıcılık puanları arasında fark bulunmamıştır. Bu sonuca göre deney grubundaki öğrencilerin algoritma konusunu öğrendikleri ve bu öğrendiklerini de kalıcı hale getirdikleri sonucuna ulaşılabilir.

Denetim odağına göre uyarlanmış harmanlanmış öğrenme ortamında eğitim alan kontrol grubu öğrencilerinin son test - kalıcılık puanları arasında fark bulunamamıştır. Bu sonuca göre de kontrol grubundaki öğrencilerin öğrenmelerini kalıcı hale getirdikleri sonucuna ulaşılmıştır.

$\mathrm{Bu}$ uygulama Bilgisayar Programcılığında öğrenim gören önlisans öğrencileri üzerinde gerçekleştirilmiştir. Algoritma konusu her ne kadar Bilgisayar Programcılığında öğrenim gören öğrenciler için önemli olsa da bilgisayar alanı ile ilgili lisans bölümleri de mevcuttur. Bu bölümlerin başında Bilgisayar Mühendisliği ve Bilgisayar ve Öğretim Teknolojileri Öğretmenliği bölümleri gelmektedir. Bu araştırmada gerçekleştirilen uygulamaların yukarıda ismi geçen lisans bölümlerinde uygulanması ile daha kapsamlı çalışmalar yapmak faydalı olacaktır. Bu uygulamada dıştan denetim ve içten denetim odağı belirlenebilen öğrencilerle uygulama gerçekleştirilmiştir. Her ne kadar denetim odağı belirlenemeyen öğrenci sayısı az da olsa bu öğrenci grubu içinde bir tasarım yapılarak araştırmaya dahil edilebilir. Bu araştırmada hem deney hem de kontrol gruplarının öğretimleri harmanlanmış öğrenme ortamında gerçekleştirilmiştir. Öğrenmenin gerçekleştirileceği ortam sınıf ortamından bağımsız sadece çevrimiçi bir öğrenme ortamı olarak tasarlanıp, incelenebilir. Bu uygulamada deney grubuna yapılandırmacı öğrenme modellerinden 5E Öğrenme modeline göre konu anlatımı gerçekleştirilmiştir. Buna benzer olarak yapılacak diğer çalışmalarda farklı öğrenme modelleri kullanılarak farklı çalışmalar yapılarak harmanlanmış öğrenme ortamı ile ilgili bu çalışmanın sonuçlarının genellenip genellenilmeyeceği incelenebilir. Bu uygulama programlama dersine yönelik bir çalışmadır. Çalışmanın farklı branş ve konu alanlarında gerçekleştirilmesi harmanlanmış öğrenme ortamında 5E öğrenme modeli konusunda alana daha fazla bilgi 
sağlaması açısından önemli olacaktır. Bu çalışmada kullanılan harmanlanmış öğrenme ortamı araştırmacı tarafindan geliştirilmiş ve uygulanmıştır. $\mathrm{Bu}$ süreçte bir ekip çalışmasına ihtiyaç duyulması nedeniyle ileride yapılacak olan çalışmalarda konu alanı uzmanlarının, yazılımcıların, grafikerlerin, öğrenme ortamı tasarımcılarının ve eğitimcilerin de ekip içerisine dahil edilmesi ile karşılaşılabilecek olumsuz sonuçlar minimuma indirilebilir. 


\section{Summary}

Purpose and Significance: In this study, it is aimed to investigate the effect of the $5 \mathrm{E}$ learning model adapted to the audit focus on the academic achievement of the students in the blended learning environment. Within the scope of this general objective, answers to the following questions were sought.

1. Taking lessons in a blended learning environment with a blended learning environment adapted to the $5 \mathrm{E}$ learning model adapted to the audit focus;

a. Is there a meaningful difference between the post-test scores of all groups?

b. Is there a meaningful difference between the test scores of the experimental group and control group students?

2. Taking lessons in a blended learning environment with a blended learning environment adapted to the 5E learning model adapted to the audit focus;

a. Is there a meaningful difference between the retention test scores of all groups?

b. Is there a meaningful difference between the retention test scores of the experimental group and control group students?

3. Is there a meaningful difference between the posttest-retention scores of the students who took the courses in the blended learning environment in accordance with the $5 \mathrm{E}$ learning model adapted to the control center?

4. Denetim odağına göre uyarlanmış harmanlanmış öğrenme ortamında ders alan kontrol grubu öğrencilerinin son test - kalıcılık puanları arasında anlamlı bir fark var midır?

Methods: Experimental design was used in this study to investigate the academic success of students in the blended learning environment adapted to the audit focus in accordance with the 5E learning model.

The independent variable of the research is the blended learning environment suitable for the control point. The argument has two different levels. These; a blended learning environment adapted to the students' 5E learning model adapted to the audit focus and a blended learning environment suitable for the control center of the students.

The dependent variables of the study are the academic achievements of the students. The research was carried out on 104 students who are students of Computer Programming Department of Computer Technologies Department of Vocational High School of Bozok University in 2011-2012 and who took "Programming Basics I" course in first year and first semester program.

A blended learning environment adapted to the teaching of the algorithm topic has been developed. This learning environment is designed in two different forms: a blended learning environment adapted to the $5 \mathrm{E}$ learning model adapted to the auditing focus of the students, and a blended learning environment suited to the auditing focus of the students.

In the study, open-ended achievement test was used to measure students' pre-knowledge levels and academic achievement after the experimental process. While this success test was being prepared, the views of five different experts were utilized. The achievement test applied to the students in the research was applied to the blended learning group 
adapted to Bloom 's cognitive domain taxonomy and sentence table and adapted to the control focus 5E learning model as well as the blended learning group adapted to the control center. Questions on the measure of success test were rated according to Bloom's cognitive domain taxonomy.

Results: The final test scores (61.58) of the students in the experimental environment were higher than the final test scores (53.07) of the students in the control environment. It was found that there was a significant difference between the retention test scores of different students in the experimental and control groups $\left(F_{(3-100)}=5.561, p<.01\right)$. In other words, the scores of these groups' academic success permanence test vary significantly depending on the different students in the audit focus group in both groups. The retention test scores (62.02) of the students studying in the experimental environment were higher than the retention scores of the students studying in the control environment (55.10). $\left(F_{(1-101)}=5.958, p<.05\right)$ between the blended learning environment according to the $5 \mathrm{E}$ learning model and the average retention test scores of the groups that were taught in the $5 \mathrm{E}$ blended learning environment.

The difference between the post-test and retention test point averages of the students in the experimental group was not significant $\left[t{ }_{(52)}=-.268, p>.05\right]$. The difference between the posttest and retention test point averages of the control group students was not significant $[t(50)=-.911, p>.05]$.

Discussion and Conclusions: As a result of this research, it was seen that the students who took the courses in the blended learning environment adapted to the $5 \mathrm{E}$ learning model were more successful in academic terms than those who took the courses in the blinded learning environment adapted to the control focus without using the $5 \mathrm{E}$ learning model and these learnings were more permanent. Among the final tests, the students with the external audit focus in the experimental group had higher academic achievement scores than the other groups. According to this result, it can be concluded that for the experimental group with external audit focus, the blended learning environment according to the 5E learning model is more effective than the academic achievement upgrade. In programming, there is the concept of "algorithm" in response to the concept of "plan" that people make especially in their daily life. The sequence of steps to be followed on the computer and in the execution of the program is also called the algorithm. In other words, the algorithm is the process steps that are transmitted to the computer to perform operations such as solving the problems and performing the checks. Algorithm can be created or written in a sequential or regular order. Regardless of how systematically and orderly it is to understand the algorithm properly, it recognizes more regular, disciplined, and disciplined learning in individuals with outside control. 


\section{Kaynakça}

Arabacıoğlu, T., Bülbül, H.İ. \& Filiz, A. (2007). Bilgisayar programlama öğretiminde yeni bir yaklaşım. Akademik Bilişim'07 - IX. Akademik Bilişim Konferansı Bildirileri [Tam Metin Basım], 31 Ocak - 2 Şubat 2007 Dumlupınar Üniversitesi, Kütahya.

Brusilovsky, P. (2003) Adaptive navigation support in educational hypermedia: the role of student knowledge level and the case for meta-adaptation. British Journal of Educational Technology, 34(4), 487-497

Carin, A. \& J. Bass. (2005). Teaching science as inquiry. Upper Saddle River, New Jersey: Pearson Prentice Hall.

Connolly, C., Murphy, E. \& Moore, S., (2009). Programming anxiety amongst computing students - a key in the retention debate? IEEE Transactions on Education, 52(1), 52-56.

Çelikkol, S. (2007). Programlamaya giriş ve algoritmalar. Trabzon: Academic Book Publishing.

Dağ, İ. (1991). Rotter' in iç-diş kontrol odaği ölçeği (RİDKOÖ)' nin üniversite öğrencileri için güvenirliği ve geçerliliği. Psikoloji Dergisi, 7(26), 10-15.

Dönmez, A. (1986). Denetim odağı: temel araştırma alanları. A. ̈̈. Eğitim Bilimleri Fakültesi Dergisi, 18(1), 259-280.

Ergin, İ. (2006). Fizik ĕgitiminde 5e modelinin öğrencilerin akademik başarısina, tutumuna ve hatırlama düzeyine etkisine bir örnek: İki boyutta atış hareketi (Yayımlanmamış Doktora Tezi). Gazi Üniversitesi, Eğitim Bilimleri Enstitüsü, Ankara.

Fish, L. (1999). Why use the 5E model for teaching science?. Tapestries Times, 1(2), 23.

Gardner, D.C. \& Warren, S.A. (1978). Careers and disabilities. A Career Education Approach. Greylock Publishers.

Hançer, A. H. (2005). Fen eğitiminde yapılandırmacı yaklaşıma dayalı bilgisayar destekli ögrenmenin öğrenme ürünlerine etkisi (Yayımlanmamış Doktora Tezi). Gazi Üniversitesi, Eğitim Bilimleri Enstitüsü, Ankara.

Horton, W. (2000). Designing web based training. NY, Chichester, Weinheim, Brisbane, Singapore, Toronto: John Wiley.

Hoşgörür, V. (2002). Sınıf yönetiminde yapısalcı yaklaşım. Eğitim Araştırmaları, 3(9), 73-78.

Kağıtçıbaşı, Ç. (1972). Sosyal değişmenin psikolojik boyutları: İzmir lise öğrencileri üzerine bir inceleme. Ankara: Sosyal Bilimler Derneği Yay.

Lorsbach, A. (2006). The learning cycle as a tool for planning science instruction. IIIinois State University. Retrieved from http://www.coe.ilstu.edu/scienceed/lorsbach/257lrcy.htm.

Martin, D. J. (2000). Elementary science methods: A constructivist approach. Belmont, CA: Wadsworth/Thomason Learning.

Newby, Diane E. (2004). Using inquiry to connect young learners to science. National Charter Institute. 
http://www.nationalcharterschools.org/uploads/pdf/resource_20040617125804_ Using\%20Inquiry.pdf sitesinden 24 Eylül 2012 tarihinde alınmıştır.

Özmen, H. (2005). Öğrenme kuramlarl ve fen bilimleri öğretimindeki uygulamalarl. Fen ve teknoloji öğretimi. S. Çepni (Ed.). Ankara: Pegem A Yayıncılık.

Öztürk, Ç. (2008). Coğrafya öğretiminde 5E modelinin bilimsel süreç becerilerine, akademik başariya ve tutuma etkisi (Yayımlanmamış Doktora Tezi) Gazi Üniversitesi, Eğitim Bilimleri Enstitüsü, Ankara.

Pines, H.A, \& Julian, J.W. (1972). Effects of task and social demands on locus of control differences in informormation processing. Journal of Personality, 40, 407-416.

Rotter, J. B. (1966). Generalized expectancies for internal versus external control of reinforcement. Psychological Monographs, 80, 1-28.

Saban, A. (2005). Öğrenme öğretme süreci yeni teori ve yaklaşımlar. Ankara: Nobel Yayın Dağıtım.

Singh, H. \& Reed, C. (2001). A white paper: Achieving success with blended learning. Lexington, MA: Centra Software.

Wilder, M. \& Shuttleworth, P. (2005). Cell inquiry: a 5e learning cycle lesson. Science Activities, 41(4), 37-43. 


\section{Ekler}

Şekil 3. Dıştan Denetimliler İçin 1E (Giriş) Aşaması

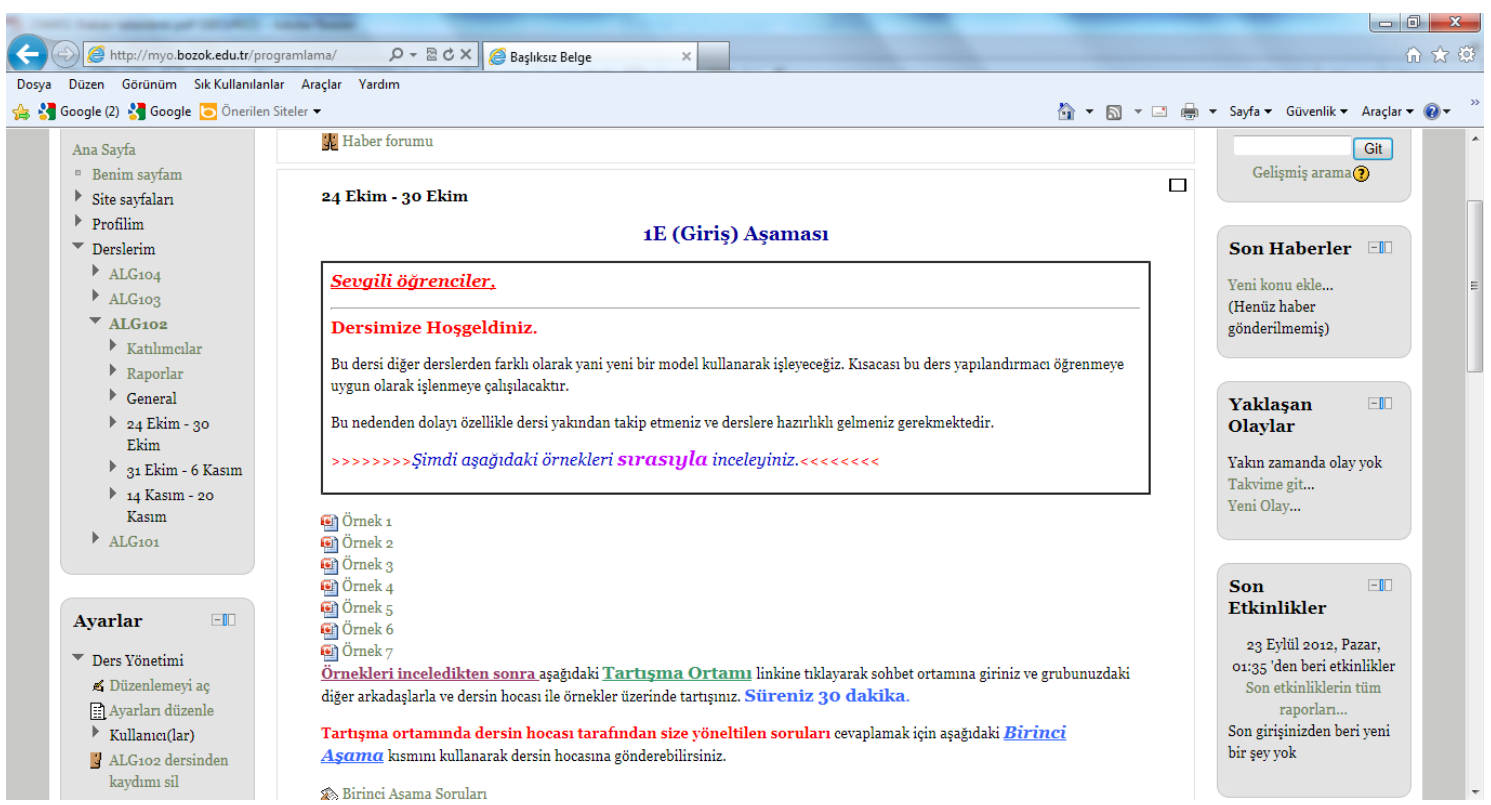

Şekil 4. İçten Denetimliler İçin 1E (Giriş) Aşaması

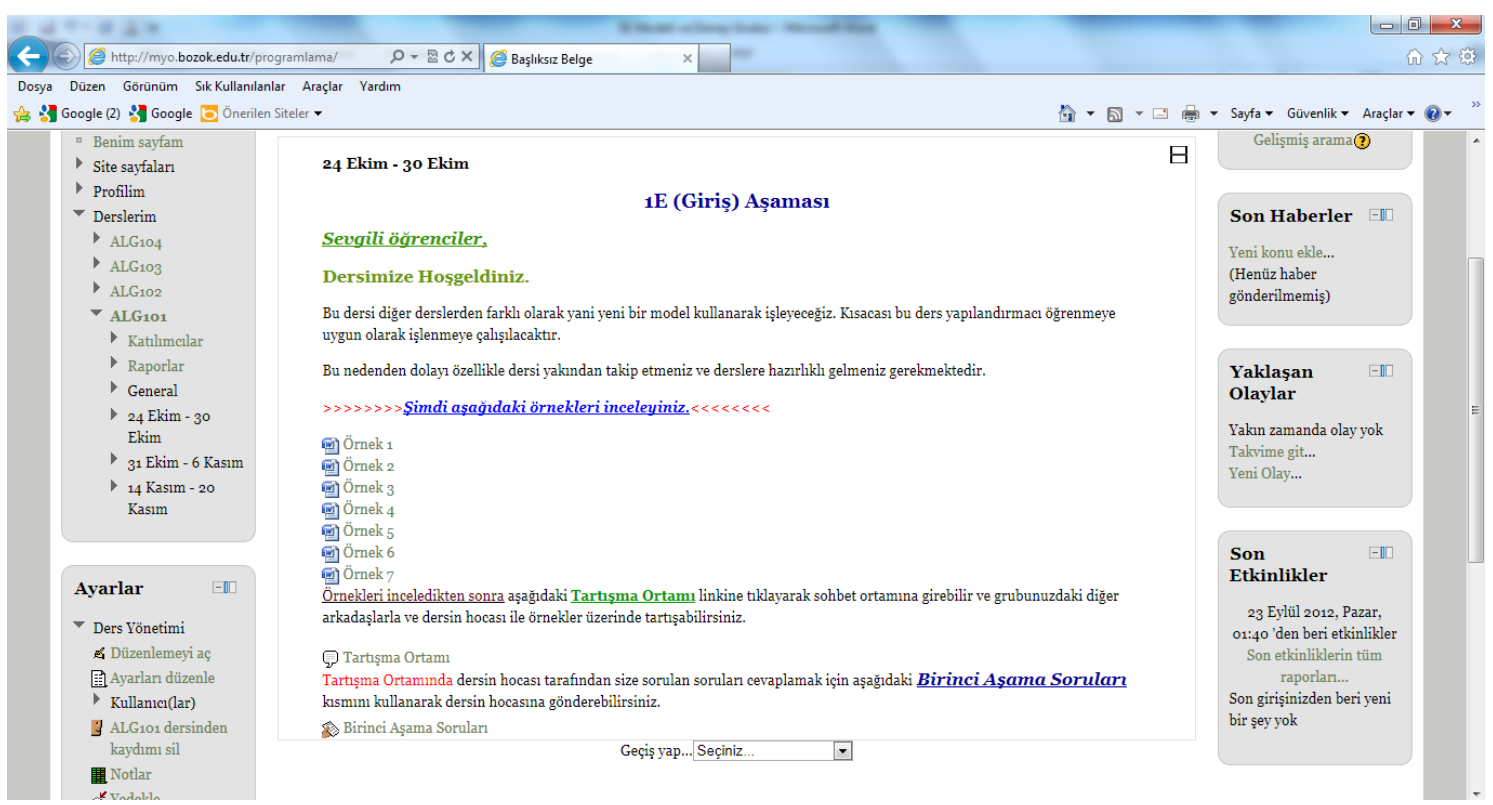

Şekil 5. Grupların Tartışma Ortamına Girdikleri Ekran

\section{Tartışma Ortamı}

Birbirinizle fikir alıșveriși yapınız.

Șimdi sohbete katl

Daha erișilebilir arayüz kullan

Geçmiș sohbet oturumlarına gözat 
Şekil 6. Grupların Ödevlerini Gönderdikleri Ekran

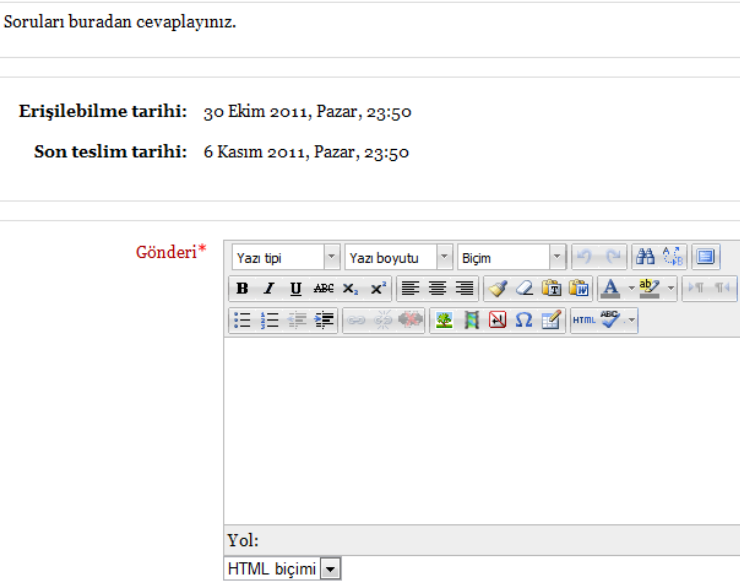

Değisiklikleri kaydet Iptal 